\title{
ON THE FUNDAMENTAL PRINCIPLES \\ IN THE CONTEMPORARY DEVELOPMENT OF RUSSIAN NEUROPSYCHOLOGY
}

\begin{abstract}
Janna M. Glozman
Lomonosov Moscow State University

Moscow

This paper deals with the development and main features of the cultural-historical approach in neuropsychology. A three step model of the evolution of Russian neuropsychology is proposed. The social and subjective features of disturbances in the pattern of mental functions and their dynamics in children and adults are discussed. The problems of the internal representation of defects, of the quality of life of patients and of their caregivers prove to be of fundamental value for contemporary neuropsychological investigations.
\end{abstract}

Keywords: neuropsychology, A.R. Luria, L.S. Vygotsky, cultural-historical approach, mediation, care-givers, internal self-representation of disease.

\section{Excursion into history}

In 1922 neuropsychologist Alexander R. Luria wrote his first large (more than 200 pages) book, Principles of a real psychology, that was not formally published at the time and the manuscript remained in Luria's archives until 2003. It is really fantastic that a 20 year old psychologist, a recent University graduate, formulated in his book the main principles of a psychological study:

- To deal with the concrete personality, the living human being, as a biological, social and psychological unity.

- To study individual regularities, uniquely determined sequences, that is, to combine a description of individual, unique processes with the study of lawful, regular processes.

- To study an individual human mind as a whole and particular mental phenomena as functions, which are elements of this whole, 
that develop in a specific human personality, with the possibility of change through the transformation of social conditions.

- To study individual significance of the psychological phenomena examined for the life of a particular personality.

Together with L.S. Vygotsky, Luria developed and followed these principles during his life, and the principles have since been adopted by his students and disciples, and formed the basis of the cultural-historical approach to psychology - which is the methodological foundation of Russian / Soviet neuropsychology.

Vygotsky and Luria developed the idea that cognitive processes descend from complex interaction and interdependence between biological factors (the individual mind), which are a part of physical nature, and cultural factors, which appear in the development of a human being. This social-historical approach in neuropsychology looks for the origins of human conscience and mental activity not inside the brain, nor in the mechanisms of nervous processes, but in the context of human social life.

Consequently, a "neuropsychological assessment should not be limited to a simple statement that one or another form of mental activity is affected. The assessment must be a qualitative (structural) analysis of the symptom under study, which specifies the observed defect and the factors causing it" (Luria, 1969, p. 306). With this, "The structure of the organism presupposes not an accidental mosaic, but a complex organization of separate systems. This organization is expressed paramountly in a functional correlation of these systems... they unite as very definite parts into an integrated functional structure" (Luria, 1932, pp. 6-7).

The development of Russian neuropsychology by students who have been trained directly by Luria or indirectly by others who were influenced by his ideas, before and after his death in 1977, coincides with the universal tendency to replace a static neuropsychology, relating the individual's behavior to fixed cerebral lesions, by a more dynamic neuropsychology, which analyzes the dynamics of brain-behavior interaction (Tupper \& Cicerone, 1990; Glozman, 1999a; 2000; 2007). The following model represents this evolution in neuropsychology through three overlapping and coexisting phases (Fig. 1).

In the first phase, neuropsychologists made emphasis on the brain and its relationship to different behaviors. The neuropsychology of that period was considered by Luria, as well as by occidental neuropsycholo- 


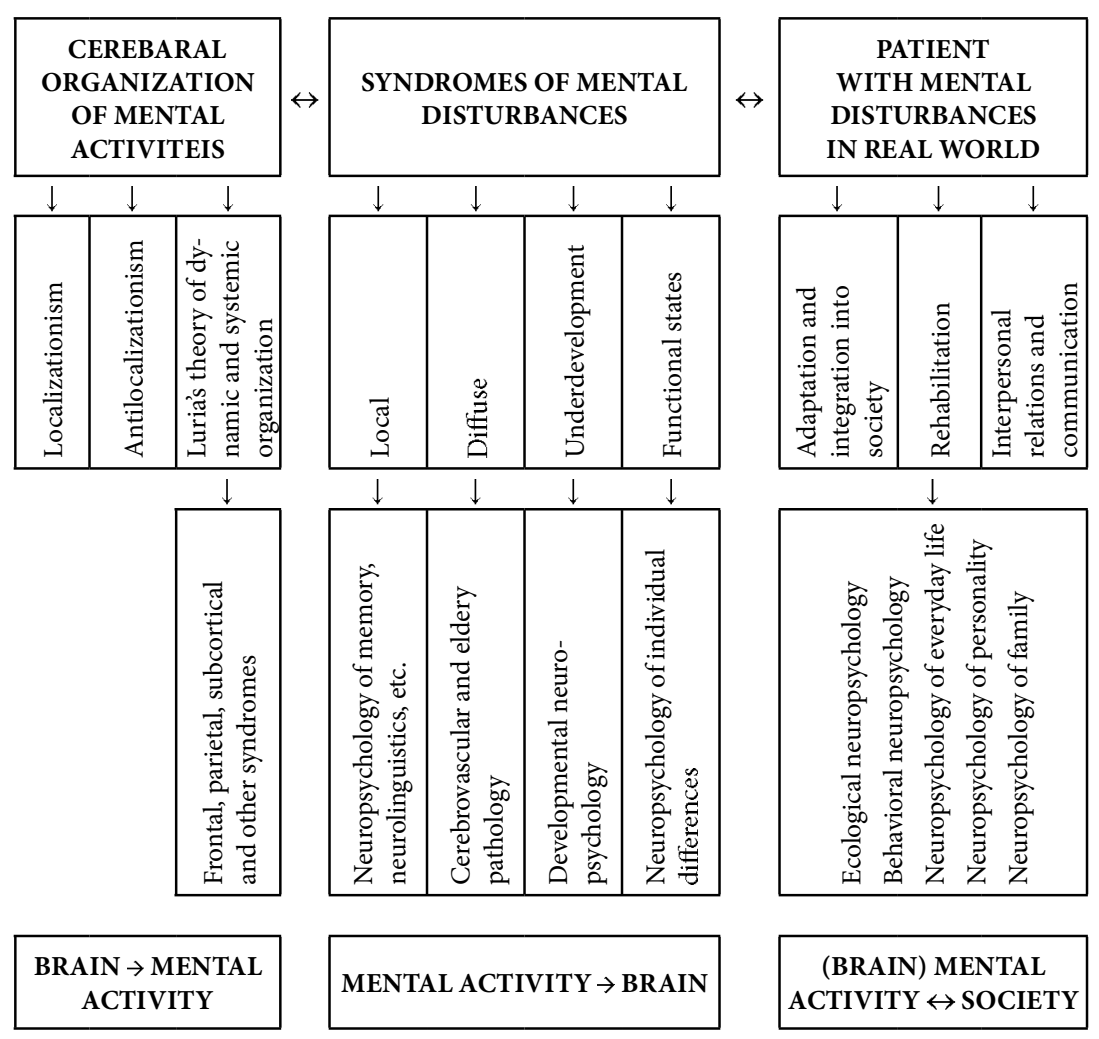

Figure 1. Model of development in neuropsychology

gists, to be a "field of practical medicine" (Luria, 1973, p. 17). The main and most valuable attainment of this phase is Luria's revision of concepts of localizationism and antilocalizationism and creation of a theory of dynamic and systematic cerebral organization of mental processes. This progress resulted in the functional analysis of different brain systems and description of frontal, parietal, temporal, and other syndromes. The recent development of this approach follows two main lines:

(1) a study of functions of the right hemisphere and interhemispheric interactions for different types of memory, perception, and reasoning for compensatory capabilities (Simernitskaya, 1978; Korsakova \& Mikadze, 
1982; Vasserman \& Lassan, 1989; Krotkova, 1998; Khomskaya \& Batova, 1998; Meerson \& Dobrovolskaya, 1998; Moskovich, 2004), and

(2) research in subcortical brain pathology, especially cognitive disturbances in patients with Parkinson's disease - a specific combination of "natural" brain alterations coming with age, necessitating a change in strategies, voluntary selection, and use of new forms of mediating mental activity for specific impairments caused by the disease (Korsakova \& Moskovichyute, 1985; Korsakova, 1998; Glozman, Levin, \& Tupper, 2004).

In the second phase of neuropsychological development, the structure of mental activity has been the focus of attention and secondarily, its localization in the brain. This phase gave birth to the understanding of different syndromes of mental disturbances: local syndromes, such as the neuropsychology of memory (Luria, 1976a; Korsakova \& Mikadze, 1982), neurolinguistics (Luria, 1976b; Akhutina, 1981; Akhutina \& Glozman, 1995) and so on; diffuse syndromes after cerebrovascular pathology (Moskovich, 2004); syndromes of underdevelopment or atypical development, with heterogeneity in the maturation of brain structures and connections, resulting in learning disabilities (Mikadze \& Korsakova, 1994; Akhutina, 1998, 2004; Akhutina \& Pylaeva, 2008; Polyakov, 2004; Mikadze, 2008; Glozman, 2009); and finally, mental dysfunctions in normal subjects in specific functional states or with some individual differences or accentuations in cognitive performances. The latter aspect gave birth to the neuropsychology of individual differences, i.e., the application of neuropsychological concepts and methods to the assessment of healthy subjects (Khomskaya, Efimova, Budyka, \& Enikolopova, 1997).

The third phase of development in neuropsychology focuses on the interrelationship between a patient and his or her environment and integrates neuropsychological characteristics, the psychology of health, and real life data. The main role of the neuropsychological assessment is rather prognostic than diagnostic to provide corrective suggestions. Neuropsychological assessment in this approach should emphasize the subject's strengths, which are important in one's correction (rehabilitation) program and should help predict their ultimate integration into society. This principle was first realized in aphasiology as the so-called "socio-psychological aspect of rehabilitation" (Tsvetkova, Glozman, Kalita, Maximenko, \& Tsyganok, 1980; Tsvetkova, 1985) and, subsequently, in the studies on the interrelationships between communication disorders 
and personality in different nosological groups (Glozman, 2004) and in developmental neuropsychology (Mikadze, 2008; Akhutina \& Pylaeva, 2008; Glozman, 2010).

The cultural-historical approach in neuropsychological rehabilitation of brain damaged patients and in remediation of learning disabled children consists in further development of the theory of mediation. L.S. Vygotsky and A.R. Luria proved that mediation is a natural process in cognitive development in children and of the psychological compensation of cognitive and physical deterioration both in children and adults. During the 1930s Luria and Vygotsky attempted to help Parkinsonian patients in the neurological hospital of Moscow University. The gait of Parkinsonian patients is often severely impaired (reduced and slow steps, difficulties in turning), but it is rather easy for the patients to go up and downstairs. Luria and Vygotsky explained this observation by the fact that the latter is a visually mediated and voluntary one. The scientists then put pieces of paper on the floor and asked patients to step over these pieces of paper. The patients could walk fluently! In essence, L.S. Vygotsky and A.R. Luria created a program which compensated for the subcortical motor disturbances in Parkinson's disease through a cortical (visual) mediation of movements (Luria, 1948; Vygotsky, 1978). The program consisted of 2 main stages:

1. A training stage, when a patient was trained to use cues with a gradual decrease in external cueing.

2. An internalization stage, when the external cues are gradually replaced by their internal images, that provide the internal means for the patient to control their own motor behavior.

My colleagues and I have used this idea of mediation as a means for transformation of functional systems in an integrated program of the rehabilitation of different mental functions: memory, attention, writing, vocabulary, counting, problem solving, space orientation, movements and the emotional sphere in parkinsonian patients and in learning disabled children (Glozman, 1999a; 2009).

We used the following methods of mediation:

VISUAL:

- External marks for walking and space orientation;

- Frames for writing;

- Externalized numbers or signs for counting and attention. 
SEMANTIC:

- Logical analysis in counting and problem solving;

- Actualization of semantic relationships for word memorization;

- Actualization of image and word relationships for vocabulary and memorization.

EMOTIONAL:

- Computer games for space orientation and vocabulary;

- Competitive situations;

- Biological feedback.

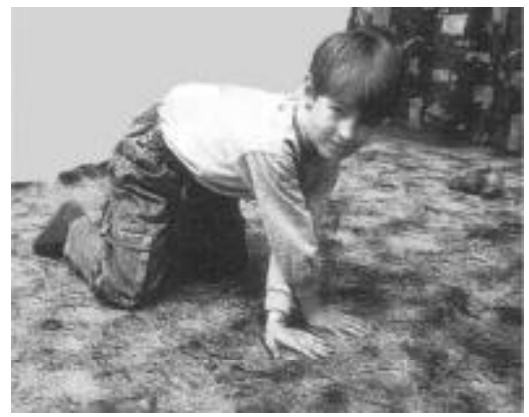

Figure 2. Mediated remediation of space orientation in movements

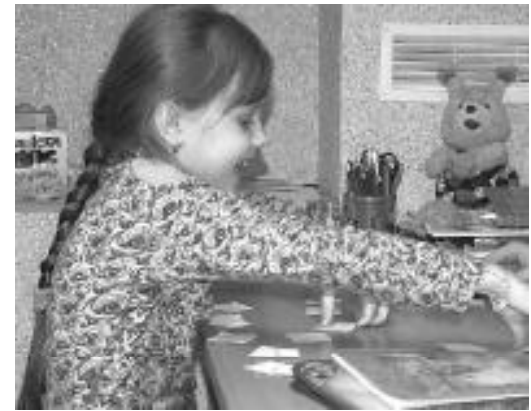

Figure 3. Mediated remediation of self-control for an ADHD child

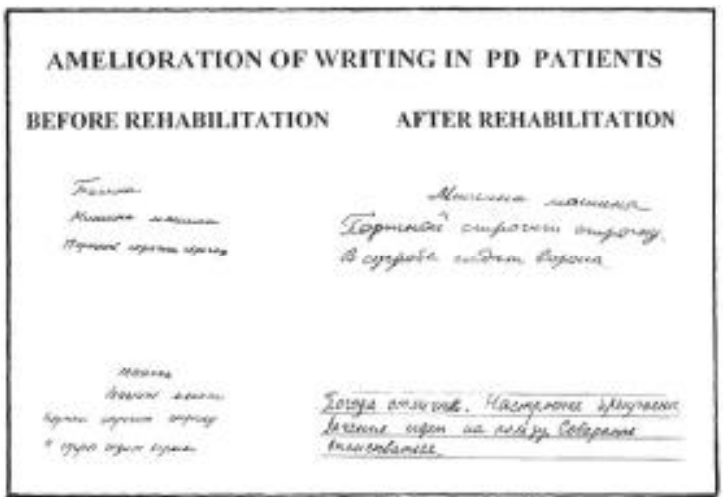

Figure 4. Mediated rehabilitation of writing in parkinsonian patients 
For instance, external means (toys, indicative of the necessary position in space, a touch on the hand saying "Stop and think about") help a child with learning problems to form and develop an ability of selfcontrol over his / her own movements and actions (Fig. 2 and 3).

Frames for writing are very efficient for compensation of micrographia in parkinsonian patients. Our longitudinal study proved such results to be stable from one to three months after rehabilitation (Fig. 4).

In all these methods the resulting effects may concern cognitive and motor abilities, the linguistic formulation of knowledge, permanence in memory, the transfer to other everyday situations, links to other fields and situations, and the motivation and attitudinal disposition of learners.

The resulting effect depends also upon teaching modalities (classical-expositive, participative-guided and peer-collaborative), optimal individualized choice of mediational means, and on interhemispheric interactions. Thus, interfunctional mediation (semantic / visual) is in most subjects more efficient than intrafunctional mediation, with some limitations for patients with specific features of interhemispheric interaction.

Mediation in teams or co-mediation may present different characteristics and challenges compared to mediations conducted by a single individual. For instance, a dyadic coping mediates the effectiveness of remediation for learning disabled children as group rehabilitation is very efficient for speech restoration in aphasic patients.

In addition, as already stated, Luria's approach presupposes a qualitative analysis of the symptom under study, based upon an understanding of the factors underlying complex psychological activities. The quantitative evaluation of disturbances is of primary value for determining the dynamics of change in cognitive functioning during neuropsychological follow-up, and for measuring the outcome of rehabilitative or remedial procedures. The scoring systems worked out by Luria's disciples take into account, beside normative reference, the qualification of the symptoms (primary or secondary defects), the conditions seen with correction of mistakes and the alternatives used to organize a successful fulfillment of the task with or without external assistance (Glozman, 1999b). 


\section{Problem of quality of life}

The new approach in neuropsychological studies has stimulated the interest of neuropsychologists to look at the subjective components of health and disease: such topics as quality of life, internal self-representation of disease and premorbid personal features. Let us remember the words of L.S. Vygotsky from 1930: "Mentality should be considered not as special processes above and outside the cerebral processes or between them, but it is their subjective expression, a particular aspect, that is a particular feature of the higher cerebral functions" (Vygotsky, 1930, p. 137).

The problem of quality of life is related to the most crucial psychological topics such as self-perception, family relationships, the effects of stress and coping, the interface of mental and physical health, and so on. The assessment of quality of life determines medical, ecological and social investments by the government and health care authorities.

It is self-evident that quality of life is a multidimensional phenomenon that needs an integrated approach to its conceptualization, but is quality of life mostly determined by the severity of the disease and the quality of care, or by the personality of the subject including certain selfconcepts, notably self-esteem and mastery, that are mostly independent of one's particular situation and are carried with someone from one situation to another? Is this disease specific or common for a wide range of disease types? Why are two patients with the same degree of the disease severity, similar treatment and symptom regression completely different in their emotional reactions to their own state?

A variety of different meanings of quality of life are presented in the neuropsychological and medical literature both for patients and their caregivers:

- As an outcome of health care and rehabilitation;

- As health status and a sign of functional disability, disease progression or regression;

- As a manifestation of one's social circumstances and external conditions;

- As a subjective internal construct of self-evaluation and psychological well-being that doesn't necessarily correspond closely to objective manifestations of health status.

Answers to the above questions and the choice among the definitions of quality of life differ between the disease-centered approach and the 
patient-centered approach in clinical psychology. The patient-centered approach means the primary focus is on the experience of individuals, their subjective interpretation and personal knowledge of health and disease, their coping strategies, self-esteem, emotional well-being and social interaction. The person-centered approach has long been considered as lacking scientific rigor, but it is becoming now more and more recognized (see review by Murrell, 1999). In accordance with this approach, optimal quality of life is determined by the patient's self-satisfaction with the mental and physical features of their own life. Therefore, emotional and social factors, familial and recreational functioning are closely associated with one's quality of life. For instance, the ability to help others or to make meaningful contributions to one's family has been viewed by the interviewed subjects as essential for maintaining the quality of their lives.

With this a patient's quality of life and satisfaction with the treatment should be calculated, not so much by the absolute degree of a preserved ability (the "quantities" of life), but through its relative preservation as compared with a premorbid level of ability. Significant correlations have been seen between quality of life scores, duration of disease and the rating of cognitive disturbances (Fig. 5 and 6), that prove an objective value of subjective measures.

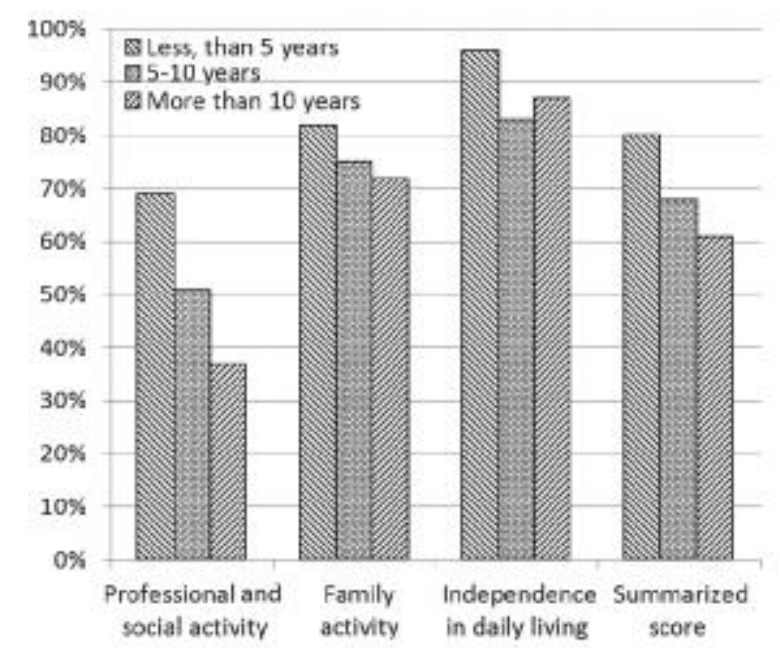

Figure 5. Quality of life and duration of disease 


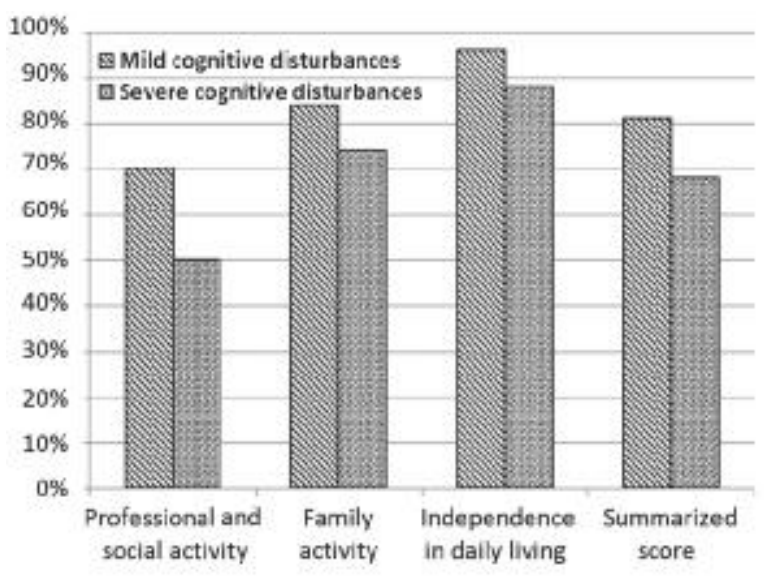

Figure 6. Quality of life and cognitive disturbances

The interdependence between quality of life of a patient and his / her caregiver is also revealed in Russian, French and Spanish studies using the same Quality of life questionnaire (Thomas, Carrois, \& Glozman, 2006).

One of the characteristic features of neuropsychology today is the proximological approach as a multidimensional analysis of both patient and his / her caregiver, that is, a study of the influence of the family on a patient's health and personality as well as of the influence of a chronic disease on caregiver's health and quality of life.

The burden of care interferes with economical well-being (decrease in professional activity, earnings loss, and expenses of patient's treatment), with the caregiver's physical health (fatigue and strain, depression and stress, need for medications and doctor's help), the caregiver's psychological functioning (job-caregiving conflict, affective and emotional donation, rare outings and holidays), and with the caregiver's social well-being: changing intra-family roles, constriction of social contacts, decreased ability to help other relatives, family conflicts. This list can be continued.

The main features of a decreased quality of life in caregivers of chronically ill patients are: difficulties in or the impossibility of facing the 
responsibilities of employment (all not-retired caregivers had to give up employment or reduce their work schedule to carry out care-giving tasks); loss of outings and holidays; problems with household management: increase of the need to take charge, the feeling of a permanent lack of time; and difficulties in attending to the needs of their children or relatives as they did previously, with sometimes negative consequences on their children's school activity. There were also symptoms of a disturbed balance in intrafamily relationships: predominantly wives complained that they seldom discussed family plans and problems with their relatives and had to decide everything by themselves while their husbands were leaders and decision-makers in their families before the disease. tors:

Family burden depends on different objective and subjective fac-

- clinical factors, such as an advanced stage of a disease, the form of a disease (for instance, for Parkinsonian patients caregivers of patients with the tremulous form were much more likely to have a mild or moderate degree of disordered quality of life, than relatives of akinetic patients), disease duration, and cognitive and behavioral impairments;

- psychological factors, such as family relationships and the length of the marriage, coping strategies, perception of availability of support, and internal representation of disease by the patient;

- social factors, such as: family position of a caregiver, age and education of a patient and caregiver, the financial status and quality of life of a patient.

I will illustrate here only 2 factors: cognitive disorders and family position of the caregiver.

It is well known that cognitive impairments are common in patients with long-standing disease, whose health status is likely to be at a low level. Our data suggest that quality of life is related not to the summarized impairment score for cognitive disorders by the care receivers, but to specific issues. For instance, in Parkinson's disease such neuropsychological symptoms as disorders of mental activity, emotional instability, exhaustibility, loss of criticism to one's own defects and disorders of orientation in time and situation were shown to be related to the degree of decrease in the caregivers's quality of life (Fig. 7). 


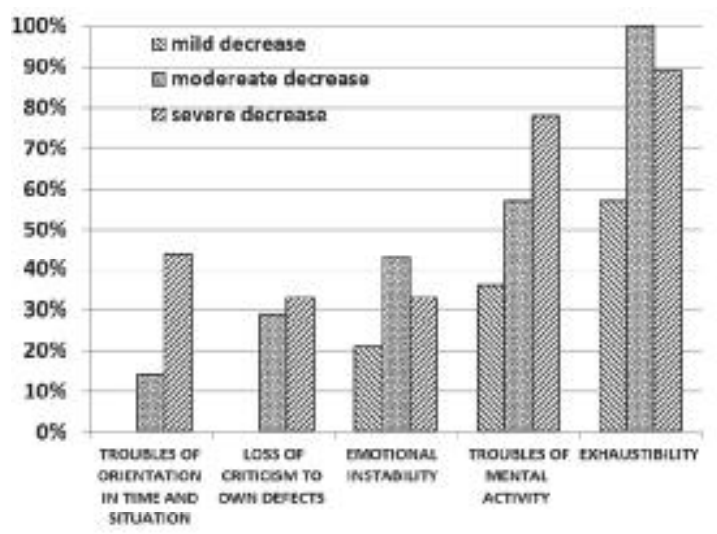

Figure 7. Cognitive disorders and quality of life of caregivers

The greatest decrease in quality of life was seen in wives of the care receiver, who are predominantly involved in providing help to their husbands. Many of them have to give up employment or reduce their work schedule to carry out care-giving tasks (Fig. 8).

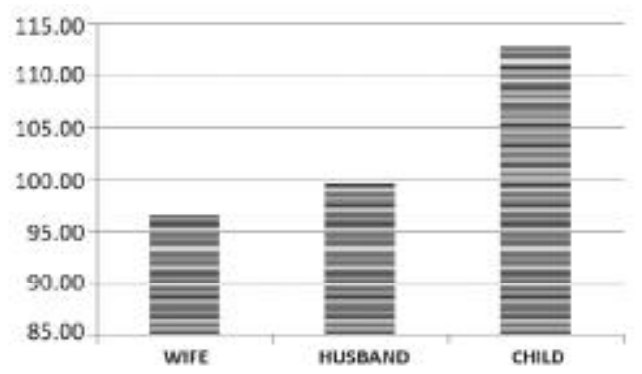

Figure 8. Quality of life and family position of caregivers (score of SQLC)

\section{Internal representation of one's own disease}

The second subjective component of psychology of health is the internal representation of one's own disease. The term was proposed in 1935 by Roman Luria - the father of Alexander Luria. He wrote 
that the internal representation of disease is "Everything the patient feels, the whole complex of his sensations... the patient's inner world, representing complex combinations of sensations and perceptions, emotions, affections, conflicts and mental trauma" (Luria R.A., 1935, p. 56).

With this definition, the internal representation of one's own disease (IRD) has a complex structure, including at least 3 interrelated aspects: a sensitive aspect (emotional reactions to the disease), a cognitive aspect (mental reflection of the disease, knowledge about it) and a voluntary aspect (an active attitude toward own disease).

A relative part of each aspect forms the types of internal representation of one's own disease. Thus, the anosognostic type shows characteristically low scores for all three aspects of IRD; high cognitive deficiency of the patient; a middle score for quality of life of the patient and a very low score for quality of life of his care-giver. The hypochondric type characteristically shows a high score for the sensitive aspect of IRD, a middle score for the cognitive aspect and a very low score for the voluntary one. There is severe depression in the patient and noted in low scores for quality of life both for patient and his caregiver. The balanced type of the internal representation of one's disease is the most favorable of all: we see high scores for the sensitive and voluntary aspects of IRD and middle scores for the cognitive one, as well as high scores for quality of life of both the patient and his / her caregiver. So, the formation of a balanced type of internal representation of a disease should be an important component of neuropsychological rehabilitation.

\section{Premorbid personality characteristics}

The third component of the psychology of health is premorbid personality characteristics. I will analyze here only depression. The psychological structure of depression has an objective component - an increase of anxiety, measured through C. Spielberger's state-trait anxiety inventory (Spilberger, 1972) and a subjective component - a decrease of selfappraisal evaluated with R. Wylie's method of self-concept assessment (Wylie, 1979). The latter measures the discrepancy between the actual, premorbid and ideal self perception of an individual. A low correlation between premorbid and ideal descriptions was considered to be an index of predisposition to depression. 
These data permitted us to differentiate 3 degrees of depression severity:

Mild

depression:

Moderate

depression:

Severe

depression:
1) Decrease of self-appraisal without an increase in traitanxiety;

2) Selective increase of trait-anxiety;

3) Increase of state anxiety together with a decrease in one index of self-appraisal.

1) Increase in both forms of anxiety;

2) Increase in trait anxiety together with a decrease in one index of self-appraisal;

3) Increase in state-anxiety together with a decrease in at least two indices of self-appraisal.

1) Increase in both forms of anxiety together with a decrease in one index of self-appraisal;

2) Increase in trait-anxiety together with a decrease in at least two indices of self-appraisal.

The degree of depression correlated with the severity of cognitive disturbances, especially with neurodynamic disturbances, that proved

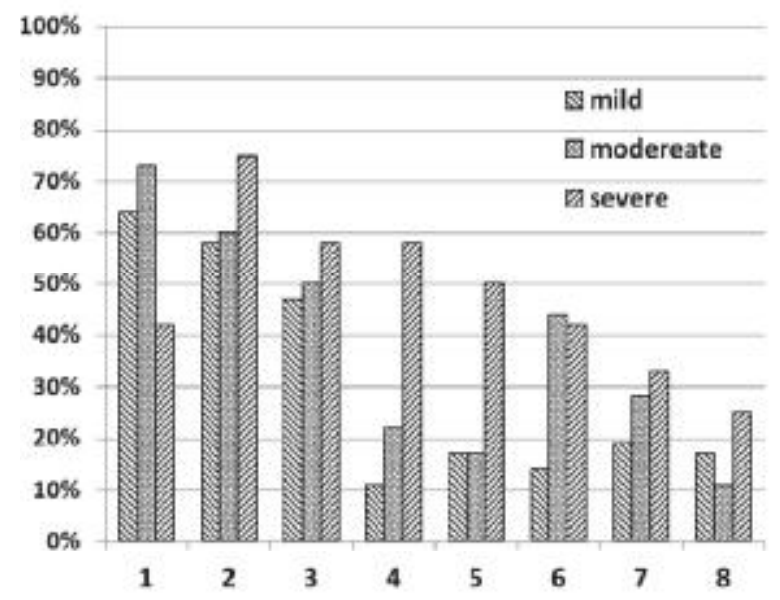

Figure 9. Cognitive disturbances in different degrees of depression. 1. Impaired reciprocal coordination. 2. Motor exhaustibility. 3. Decrease of memory volume. 4. Decrease of memory stability. 5. Categorization defects. 6. Counting disturbances. 7. Slowing of verbal activity. 8. Dysprosody. 
once more the objective neuropsychological value of subjective measures. Different patterns of cognitive disturbances characterized each degree of depression (Fig. 9).

It should be stressed that all patients with total regression (normalization) of depression after pharmacological and neuropsychological treatment had normal scores for premorbid self-appraisal. Also, vice versa, all but one patient with partial regression of depression manifested a decrease in premorbid self-appraisal and an increase in traitanxiety.

So, one should differentiate the objective and subjective mediating factors in rehabilitation that are closely interrelated and interdependent. The objective factors are various teaching and treatment techniques and modalities and the subjective mediating factors are the internal representation of disease and premorbid personality characteristics.

\section{Conclusion}

Patients with less cognitive disturbances, lower depression and anxiety, and a more balanced type of internal representation of their disease show better results in rehabilitation.

The internal representation of defects correlated more with emotional disturbances than with real motor deficits.

A premorbid predisposition to depression is crucial to determine, as the degree of its severity after onset of disease affects the patients' potential to benefit from pharmacological and neuropsychological therapy. And vice versa, one's levels of depression and anxiety tend to be normalized during neuropsychological rehabilitation.

The patient-caregiver dyad should be viewed as a unit when detecting problematic situations and targeting appropriate and efficient interventions by professional practitioners.

Therefore, contemporary neuropsychology stresses more and more the human subjective experience that is conceived as something that is constituted in one's relationship with the physical and social world through human activity. 


\section{References}

Akhutina, T.V.(1981). Organizaciâ slovarâ čeloveka po dannym afaziologii [Lexical Organization upon Aphasiological Data]. In A.A. Zalevskaya (Ed.), Psiholinvističeskie issledovaniâ v oblasti leksiki i fonetiki [Psycholinguistic Studies of Vocabulary and Phonetics] (pp. 3-12). Kalinin: KGU.

Akhutina, T.V. (1998). Nejropsihologiâ individual'nyh različij detej kak osnova ispol'zovaniâ nejropsihologičeskih metodov v škole [Neuropsychology of Individual Differences in Children as a Basis for the Application of Neuropsychological Methods at School]. In E.D. Khomskaya \& T.V. Akhutina (Eds.), I Meždunarodnẩ konferenciâ pamâti A.R. Luriâ. Sbornik dokladov [First International Luria Memorial Conference Proceedings] (pp. 201-208). Moscow: RPO.

Akhutina, T.V. (2004). Writing: Assessment and Remediation. In T.V. Akhutina, J.M. Glozman, L.I. Moskovich, \& D. Robbins (Eds.), A.R. Luria and Contemporary Psychology: Festschrift Celebrating the Centennial of the Birth of Luria (pp. 125-145). New York: Nova Science.

Akhutina, T.V., \& Glozman, J.M. (1995). The Neurolinguistic Study of Semantics. Aphasiology, 9 (2), 143-152.

Akhutina, T.V., \& Pylaeva, N.M. (2008). Preodolenie trudnostej učeniâ: nejropsihologičeskij podhod [Learning Problems Overcoming. Neuropsychological Approach] Saint Petersburg: Piter.

Glozman, J.M. (1999a). Russian Neuropsychology after Luria. Neuropsychology Review, 9 (1), 33-44.

Glozman, J.M. (1999b). Quantitative and Qualitative Integration of Lurian Procedures. Neuropsychology Review, 9 (1), 23-32.

Glozman, J.M. (2000). Neuropsychology in the former USSR. In W.E. Craighead \& C.B. Nemeroff(Eds.), The Corsini Encyclopedia of Psychology and Behavioral Science. Vol. 4 (pp. 1730-1733). New York: John Wiley \& Sons.

Glozman, J.M. (2004). Communication Disorders and Personality. New York: Kluwer Academic / Plenum Publishers.

Glozman, J.M. (2007). A.R. Luria and the History of Russian Neuropsychology. Journal of the History of the Neurosciences, 16 (1-2), 168-180.

Glozman, J.M. (2009). Nejropsihologiâ detskogo vozrasta [Developmental neuropsychology]. Moscow: Akademiâ.

Glozman, J.M., Levin, O.S., \& Tupper, D.E. (2004). Executive Behavior after Cortical and Subcortical Brain Damage. In T.V. Akhutina, J.M. Glozman, L.I. Moskovich, \& D. Robbins (Eds.), A.R. Luria and Contemporary Psychology: Festschrift Celebrating the Centennial of the Birth of Luria (pp. 65-77). New York: Nova Science. 
Khomskaya, E.D., \& Batova, N.Ya. (1998). Mozg i èmocii [Brain and Emotions]. Moscow: Rossijskoe pedagogičeskoe agentstvo.

Khomskaya, E.D., Efimova, I.V., Budyka, E.V., \& Enikolopova, E.V. (1997). Nejropsihologiâ individual'nyh različij [Neuropsychology of Individual Differences]. Moscow: Rossijskoe pedagogičeskoe agentstvo.

Korsakova, N.K. (1998). Nejrogerontopsihologiâ: razvitie idej školy A.R. Lurii [Neuropsychogerontology: Development of A.R. Luria's School of Ideas]. In E.D. Khomskaya \& T.V. Akhutina (Eds.), I Meždunarodnaâ konferenciâ pamâti A.R. Luriâ. Sbornik dokladov [First International Luria Memorial Conference Proceedings] (pp. 249-254). Moscow: RPO.

Korsakova, N.K., \& Mikadze, Yu.V. (1982). Nejropsihologičeskie issledovaniâ pamâti: itogi i perspektivy [Neuropsychological Studies of Memory: Results and Perspectives]. In E.D. Khomskaya, L.S. Tsvetkova, \& B.V. Zeigarnik (Eds.), A.R. Luriâ $i$ sovremennâ̂ psihologiâ [A.R. Luria and Modern Psychology] (pp. 101-110). Moscow: MGU.

Korsakova, N.K., \& Moskovichyute, L.I. (1985). Podkorkovye struktury mozga $i$ psihičeskie processy [Subcortical Structures and Mental Processes]. Moscow: MGU.

Krotkova, O.A. (1998). Mežpolušarnoe vzaimodejstvie i processy vosstanovleniâ funkcij pri očagovyh poraženiâh mozga [Interhemispheric Interaction and Rehabilitation Processes after Local Brain Damages]. In E.D. Khomskaya \& T.V. Akhutina (Eds.), I Meždunarodnâ̂ konferenciâ pamâti A.R. Luriâ. Sbornik dokladov [First International Luria Memorial Conference Proceedings] (pp. 126-131). Moscow: RPO.

Luria, A.R. (1932). The Nature of Human Conflicts. New York: Liveright.

Luria, A.R. (1948). Vosstanovlenie funkcij mozga posle voennoj travmy [Restoration of Brain Functions after Brain Injury]. Moscow: AMN SSSR. (English translation: New York: Macmillan / Pergamon, 1963).

Luria, A.R. (1969). Vyšsie korkovye funkcii čeloveka i ih narušeniâ pri lokal'nyh poraženiâh mozga [Higher Cortical Functions in Man]. 2nd ed. Moscow: MGU. (English translation: Basic Books, 1980).

Luria, A.R. (1973). The Working Brain. An Introduction to Neuropsychology. London, Penguin Books.

Luria, A.R. (1976a). The Neuropsychology of Memory. Washington: Winston.

Luria, A.R. (1976b). Basic Problems of Neurolinguistics. The Hague, Mouton.

Luria, A.R. (2003). Principy real'noj psihologii [The Principles of Real Psychology]. In A.R. Luria. Psihologičeskoe nasledie. Izbrannye trudy po obŝej psihologii [Psychological Tribute. Selected Works in General Psychology] (pp. 295-384). Moscow: Smysl.

Luria, R.A. (1935). Vnutrennââ kartina bolezni i âtrogennye zabolevaniâ [Internal Representation of Disease and Iatrogenic Pathologies]. Moscow: Biomedgiz. 
Meerson, Ya.A., \& Dobrovolskaya, N.V. (1998). Narušenie vospriâtiâ absolûtnoj i otnositel'noj lokalizacii ob"ektov v glubine prostranstva (agnoziâ glubiny) pri očagovom poraženii pravogo i levogo polušarij golovnogo mozga čeloveka [Disorders in Perception of Absolute and Relative Objects Localization in Spatial Depth (Depth Agnosia) after Focal Damage of the Right or Left Cerebral Hemisphere]. In E.D. Khomskaya \& T.V. Akhutina (Eds.), I Meždunarodnaâ konferenciâ pamâti A.R. Luriâ. Sbornik dokladov [First International Luria Memorial Conference Proceedings] (pp. 87-94).Moscow: RPO.

Mikadze, Yu.V. (2008). Nejropsihologiâ detskogo vozrasta [Developmental Neuropsychology]. Saint Petersburg: Piter.

Mikadze, Yu.V., \& Korsakova, N.K. (1994). Nejropsihologičeskaâ diagnostika i korrekciâ mladših škol'nikov [Neuropsychological Diagnosis and Correction of Primary School Children]. Moscow: IntelTeh.

Moskovich, L.I. (2004). Cerebral Hemisphere Asymmetry on the Cortical and Subcortical Levels. In T.V. Akhutina, J.M. Glozman, L.I. Moskovich, \& D. Robbins (Eds.), A.R. Luria and Contemporary Psychology: Festschrift Celebrating the Centennial of the Birth of Luria (pp. 11-13). New York: Nova Science.

Murrell, R. (1999). Quality of Life and Neurological Illness: A Review of the Literature. Neuropsychology Review, 9 (4), 209-230.

Polyakov, V.M. (2004). Neuropsychological Screening of Child Population. In T.V. Akhutina, J.M. Glozman, L.I. Moskovich, \& D. Robbins (Eds.), A.R. Luria and Contemporary Psychology: Festschrift Celebrating the Centennial of the Birth of Luria (pp. 93-105). New York: Nova Science.

Simernitskaya, E.G. (1978). Dominantnost' polušarij [Hemispheric Dominance]. Moscow: MGU.

Spielberger, Ch.D. (Ed.). (1972). Anxiety: Current Trend in Theory and Research. New York: Academic Press.

Thomas, P., Carrois, F., \& Glozman, J.M. (2006). La proximologie et la maladie de Parkinson. La Revue Francophone de Gériatrie et de Gérontologie, 122, XIII, 58-65.

Tsvetkova, L.S. (1985). Nejropsihologičeskaâ reabilitaciâ bol'nyh [Neuropsychological Rehabilitation of Patients]. Moscow: MGU.

Tsvetkova, L.S., Glozman, J.M., Kalita, N.G., Maximenko, M.Yu., \& Tsyganok, A.A. (1980). Social'no-psihologičeskij aspekt reabilitacii bolnyh s afaziej [Socio-Psychological Aspect of Aphasics Rehabilitation]. Moscow: MGU.

Tupper, D.E., \& Cicerone, K.D. (1990). Introduction to the Neuropsychology of Everyday Life. In D.E. Tupper \& K.D. Cicerone (Eds.), The Neuropsychology of Everyday Life: Assessment and Basic Competencies (pp. 3-18). Boston: Kluwer Academic Publishers. 
Vasserman, L.I., \& Lassan, L.P. (1989). Lateral'nyj èffekt podkorkovogo stereotaksičeskogo razrušeniâ na posleoperacionnuû dinamiku psihičeskih funkcij u bol'nyh èpilepsiej [Effect of Lateralization of Subcortical Stereotaxic Destruction on Post Surgery Dynamics of Mental Functions in Subjects with Epilepsy]. In Kliničeskie aspekty funkcional'noj asimmetrii mozga [Clinical Aspects of the Problem of Brain Functional Asymmetry]. Minsk.

Vygotsky, L.S. (1930/1982). O psihologičeskih sistemah [On psychological systems]. In Vygotsky, L.S. Sobranie sočinenij. T. 1 [Collected Works. Vol. 1] (pp. 109-132). Moscow: Pedagogika.

Vygotsky, L.S. (1978). Mind in Society. The development of higher psychological processes. Cambridge: Harvard University Press.

Wylie, R. (1979). The Self Concept. Lincoln: University of Nebraska Press. 